\title{
Electrical Conductivity and Aftershock Activity in Seismically Active Region of Chamoli, Lesser Himalayas
}

\author{
S. Kareemunnisa Begum \\ Department of Geophysics, Andhra University, Visakhapatnam, India \\ Email: skbegum.geophy@auvsp.edu.in
}

How to cite this paper: Begum, S.K. (2017) Electrical Conductivity and Aftershock Activity in Seismically Active Region of Chamoli, Lesser Himalayas. Open Journal of Earthquake Research, 6, 117-134. https://doi.org/10.4236/ojer.2017.62007

Received: February 23, 2017

Accepted: May 16, 2017

Published: May 19, 2017

Copyright $\odot 2017$ by author and Scientific Research Publishing Inc. This work is licensed under the Creative Commons Attribution International License (CC BY 4.0).

http://creativecommons.org/licenses/by/4.0/ (c) (i) Open Access

\begin{abstract}
The Chamoli earthquake (M6.8) of $29^{\text {th }}$ March 1999 in Himalayan region is one of the recent devastating earthquakes that has killed more than a few hundred lives and caused damage in the vicinity of Chamoli and Gopeshwar districts of Gharwal Himalayan region. A wide band $(8192-0.008 \mathrm{~Hz})$ magnetotelluric (MT) study has been carried out in the epicentral zone after the earthquake during May-June, 1999 to understand the processes related to tectonic activity. A total of 23 sites were occupied passing through the epicenter along NE-SW and E-W oriented profiles passing through the epicenter. In the present study, the results obtained along NE-SW profile are presented. The deeper electrical structure shows a north-eastward dipping electrical conductor $(50-100 \Omega \mathrm{m})$ and correlates well with the regional tectonics of the region. Interestingly, the concentration of hypocenters is located at the transition zone of resistor (brittle) and conductor (ductile) at depths of around $10-15$ $\mathrm{km}$. These results are discussed with reference to the seismotectonics of the region.
\end{abstract}

\section{Keywords}

Himalayas, Magnetotellurics, Electrical Conductor, Seismicity, Transition Zone

\section{Introduction}

The Himalayas, the highest mountain chain in the world (Molnar and Chen, 1983 [1]; Nakata, 1989 [2]; Demets et al., 1990 [3]; Bilham et al., 1998 [4]) is believed to have been formed due to continent collision of the Indian and Eurasian plates. Because of the intense tectonic activity, the entire region has experienced major earthquakes. It is reported that fourteen major earthquakes with $\geq 7.5$ magnitude occurred during the period 1897-1992 (Gupta et al., 1995a [5]; Kayal 
et al., 2001 [6]). The regions of Garhwal and Kumaun have experienced a large earthquake during May, 1803 and are reported to have caused severe damages to the property and also about $80 \%$ percent of the population in the area vanished under the debris (Raturi, 1988 [7]). While such is the tectonic activity in the region, the recent earthquakes in the Garhwal Himalayan region-one near Uttarkashi during 1991 and the recent Chamoli 1999-have killed more than a few hundred lives. This has demanded to probe the region to understand the processes related to tectonic activity. Towards this direction magnetotelluric (MT) studies have been carried out in Chamoli and Gopeshwar districts of the Garhwal Himalayas. The MT sites in the region are located in the lesser Himalayas and are characterized by Nappe, Clippe and Shuppen zones, bounded by faults and thrusts zones. Major lithological units are formations belonging to Vaikrita, Almora, Tejam, Jaunsar, Ramgarhand Damtha formations. The Vaikrita group of rocks belongs to higher Himalayas and consists of high grade metamorphic rocks of granite and granite gneisses. Chamoli and Gopeshwar regions are Criss crossed with complex thrust zones and faults (Figure 1) and consists of Precambrian sediments (Valdiya, 1980 [8], Kareemunnisa Begum, S, 2003 [9].

It is believed that part of the Indian crust was cracked off during the process

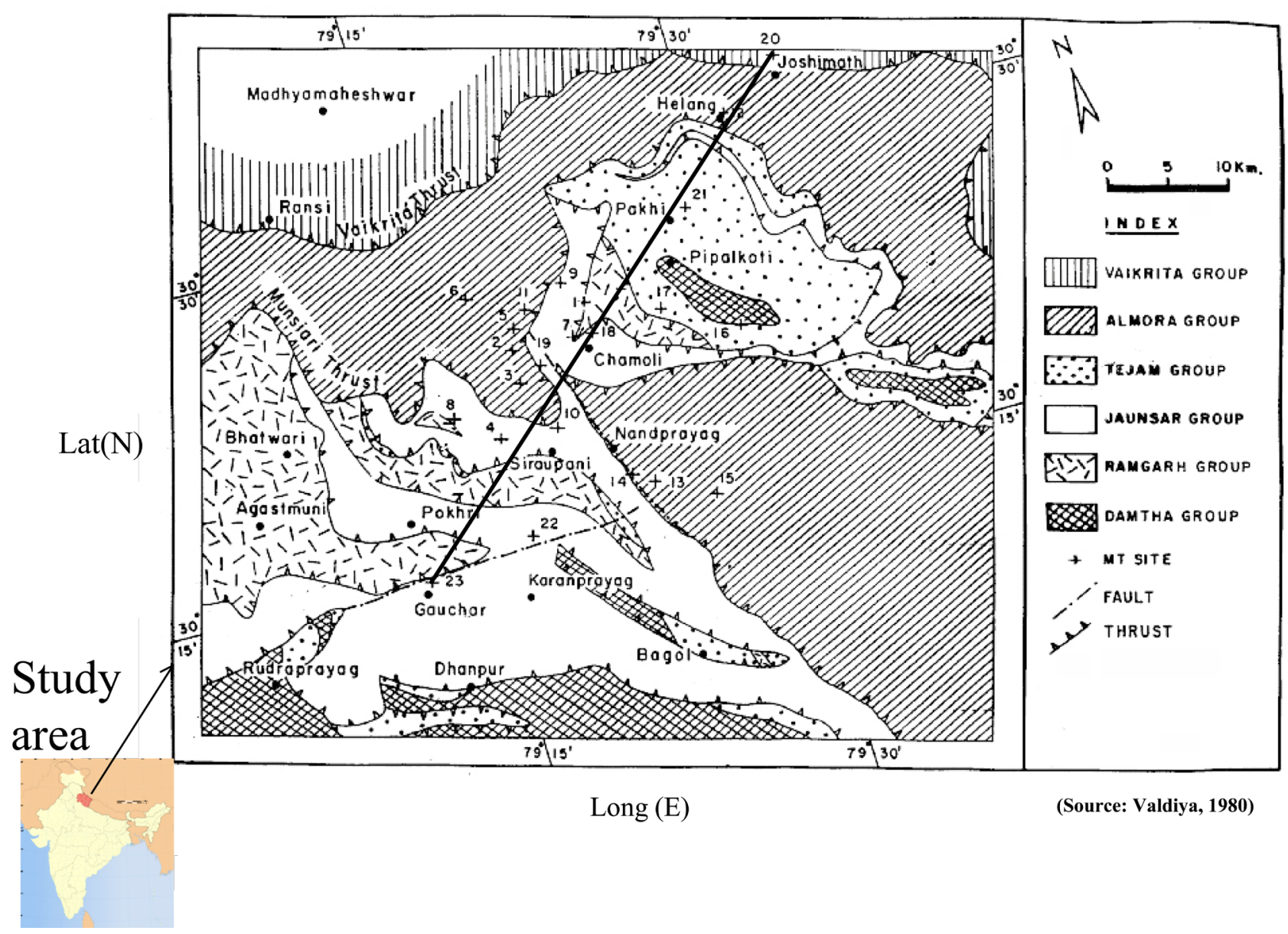

Figure 1. Location map of MT sites over a geological map of Chamoli earthquake epicentral zone. 
of underthrusting of Indian plate beneath the Tibetan plate. This has resulted in crustal thickening and also the development of shallow basins filled with tertiaries (Lefort, 1975 [10]). The underthrusting process beneath the Tibetan plateas suggested by various evidences (Molnar, 1990 [11]; Bilham et al., 1998 [4]; Bilham et al., 2001 [12]) has also induced various metamorphic processes and crustal melting (Searle et al., 1997 [13]; Henry et al., 1996 [14]). In the context, geophysical studies can play an important role in understanding the deep crustal properties. It is known that the electrical conductivity parameter of the crust depends on the fluid content, pore and permeability distribution in the rocks and also the petrological properties (Marquis and Hyndman, 1992 [15]; Yardley and Valley, 1997 [16]). Given such processes can exist in the Himalayas, it is appropriate to study the deep electrical structure of the crust and its bearing on tectonics using one of the well known techniques namely the magnetotellurics.

Main Central Thrust (MCT) defined by Valdiya (1980 [8]) is the boundary between the high grade metamorphic rocks of Vaikrita group and low grade metamorphic rocks of Almora group. This thrust is a major tectonic boundary and traceable all along the Himalayan region. It is demarcated as a zone of ductile shearing and thrusting dipping about $30^{\circ}$ northward, manifested as abrupt change in structures and grade of metamorphism (Gansser, 1964 [17]). Lower boundary of MCT zone is the Munsiari thrust and most of the epicentres in the lesser Himalaya are concentrated near this thrust (Ni and Barazangi, 1984 [18]). The well mapped faults-Alakananda fault near Karnaprayag and the Gopeshwar fault are extending NNW-SSE direction from Nandaprayag to Gopeshwar are prominent in the region (Valdiya, 1980 [8]). Detailed geophysical studies carried out in this region to understand the subsurface structure are very few (Valdiya, 1980 [8]; Arora et al., 1992 [19], Cotton et al., 1996 [20] and Lemmonier et al., 1999 [21]) although fairly detail investigations have been carried out in Tibetan Himalayas by INDEPTH surveys (Zhao et al., 1993 [22]; Nelson and Zhao; 1996 [23]; Li et al., 2003 [24]). One of the main objectives of the present study is to find any relation between electrical conductivity and seismic activity. At few places elsewhere in the world, a few seismically active regions are associated with anomalous conductivity. In India also earlier study by Gupta et al., 1996 [34] have established the presence of anomalous conductivity near Latur epicentral zone. Accordingly I would like to see such anomalous structures exist in this region or not. The Global Positioning System (GPS) studies have provided three fundamental constraints concerning the tectonic frame work of the Indian plate: its overall stability $(<0.01 \mu$ strain/yr), its velocity with respect to Asia $\left(58 \pm 4 \mathrm{~mm} / \mathrm{yr}\right.$ at $\left.\mathrm{N} 44^{\circ} \mathrm{E}\right)$ and its rate of collision with southern Tibet (20.5 $\pm 4 \mathrm{~mm} / \mathrm{yr}$ ) (Bilham et al., 1998 [4]). The present MT study is an attempt in that direction to map the deep geoelectric structures.

\section{CHAMOLI REGION}

The Occurrence of $28^{\text {th }}$ March 1999 Chamoli earthquake (Mb 6.8) is the recent earthquake in the Himalayan region. The Himalayas being a big research laboratory, one can do many observations to understand the geodynamic 
processes. From the list of 13 earthquakes that have occurred in the past 97 years in Kumuan-garhwal region, $M \geq 6$ earthquakes seem to repeat every eight years (Rastogi, 2000 [41]). To understand the seismotectonics of the Himalayan region in the aftermath of the occurrence of the earthquake at Chamoli which falls under the Garhwal Himalayan region, magnetotelluric (MT) studies have been taken up by NGRI near or across the main Central Thrust(MCT).

As described earlier, Chamoli earthquake has caused extensive damage to life and property. The epicentral tract of this event is oriented in the $\mathrm{E}-\mathrm{W}$ direction. The aftershocks for few days are concentrated in an area of $40 \times 30 \mathrm{~km}$ which is bounded by the MCT towards the north and the Alkananda fault in the south (Rastogi, 2000 [41]) and (Mandal et al. 2001 [40]) have suggested a source model of this event on the basis of recorded data using the seismotectonic setting of the area. They have summarized that the Chamoli event nucleated at the intersection of a transverse fault and rupture propagated towards west along the detachment surface at $20 \mathrm{~km}$ depth. The hypocenters of the Chamoli earthquake sequence lie above the plane of detachment.

In order to understand the problem of increased seismicity in Himalayan arc, in general and near Chamoli region in particular there is a need to increase our knowledge on the crustal/mantle structure and composition and also the physical processes related to generation of seismicity in this region, detailed study of subsurface is as important as the studies related to monitoring of seismic activity as well as other well established physical parameters like strain rate and seismic velocities in seismically active regions.

Information on the depth to the interface between brittle and ductile zones that could be obtained from electrical structure in the earth's crust is known to have a close bearing on the characterization of seismicity and seismotectonics processes of any region. Delineating subsurface electrical interfaces plays a crucial role in such a demarcation and mapping of transition between brittle and ductile zones. The subsurface information that I retrieve through Magnetotelluric application could also be effectively interpreted in terms of lateral subsurface heterogeneities reflecting possible rheological changes that are known to be closely linked to seismogenic processes. It is also believed that fluid filled zones in the crust play a major role in generating seismicity in the region. Mapping subsurface conductors, which might represent any of the significant features like fluid filled zones in the earth's crust, feeder dykes, structural features like faults and shear zones, magma chambers, partial melts etc should provide several basic vital clues to unravel the possible sources responsible for intraplate seismicity in the Indian stable continental region.

In the present study I report the results of magnetotelluric technique cross the thrust and faults of Himalayas near MCT.

\section{Data Acquisition}

Subsequent to Chamoli earthquake of March 29, 1999 magnetotelluric study was taken up during May-June 1999 using GMS 05 system of M/s Metronix, Ger- 
many, a wide band digital system to understand the subsurface geoelectric structure. A total number of 23 sites were occupied covering Karnaprayag, Nandaprayag, Chamoli, Pipalkoti, Joshimath areas and also along Gopeshwar-Pokhri, Chamoli-Mandal roads. Inaccessibility due to hills and proximity of electric power lines from many small scale hydropower plants are some of the factors laid restrictions to occupy more number of sites.

In MT method magnetic and electric field variations have been measured using induction coils and non-polarizing $\mathrm{Cd}-\mathrm{CdCl}_{2}$ electrodes respectively. The data were acquired in four different frequency bands in 8192-0.008 Hz range. High frequency signals provide information at shallow depths, whereas the low frequency signals probe the earth to deeper levels. The analysis of time varying magnetic and electric signals provides MT impedance tensor elements.

\section{Data Analysis and Inversion}

Impedance tensor elements have been computed using robust analysis procedures in the wide frequency range corresponding to the large penetration depths from about $0.1-50 \mathrm{~km}$. The impedance tensor elements after robust processing of the data have been decomposed to reduce the effects of localized galvanic distortions (Groom Bailey, 1989 [25]). Figure 2 shows an example of decomposed and static shift corrected data for a site. Static effects have been corrected based on statistical analysis (Jones, 1988 [26]). Although the region around MCT is complex representing 2-D and 3-D heterogeneity, the structure seems to be nearly 1-D near the surface and 2-D at depth, contributions of 3-D appears to be minimum from Kao and Orr dimensionality parameters (Kao \& Orr, 1982 [27]) and also from Mohr circle analysis (Lilley, 1974 [28]; Lilley, 1976 [29]; Lilley, 1993a [30], 1993b [31]). As an example, the dimensionality parameters (Kao \& Orr, 1982 [27] for a site S7 is presented (Figure 3). 1D, 2D and 3D factors shown in this Figure 3 is the component of each factor at the location. For example, if $1 \mathrm{D}$ has highest value, then it can be said that the earth below consists of horizontal layers.

The data were inverted using rapid relaxation inversion (RRI) technique (Smith and Booker, 1991 [32]). The 2-D model along Gaucher towards southwest and Joshimath towards the Northeast direction is estimated. Joint inversion of TE and TM mode data is useful to obtain good representation of subsurface electrical structure. The data were inverted together with $\mathrm{TE}$ mode $\left(\mathrm{N} 135^{\circ} \mathrm{E}\right)$ oriented along the strike and $\mathrm{TM}$ mode $\left(\mathrm{N} 45^{\circ} \mathrm{E}\right\}$ across the strike after decomposition.

The Z-strike values of many sites have indicated $\mathrm{N} 45^{\circ} \mathrm{E}$ electric strike, and some have shown EW. It is consistent with the regional geological strike of Himalayan formation nearly $\mathrm{N} 135^{\circ} \mathrm{E}$ (Figure 4). The models from the 20 inversion are derived with two initial models: one -the half-space as initial model and the other is stitched model constructed from 1-D modeling results. The two models derived after inversions are nearly identical and here the former is presented. During inversion of data the relevant values ( $\alpha$ and eta) for inversion parameters 

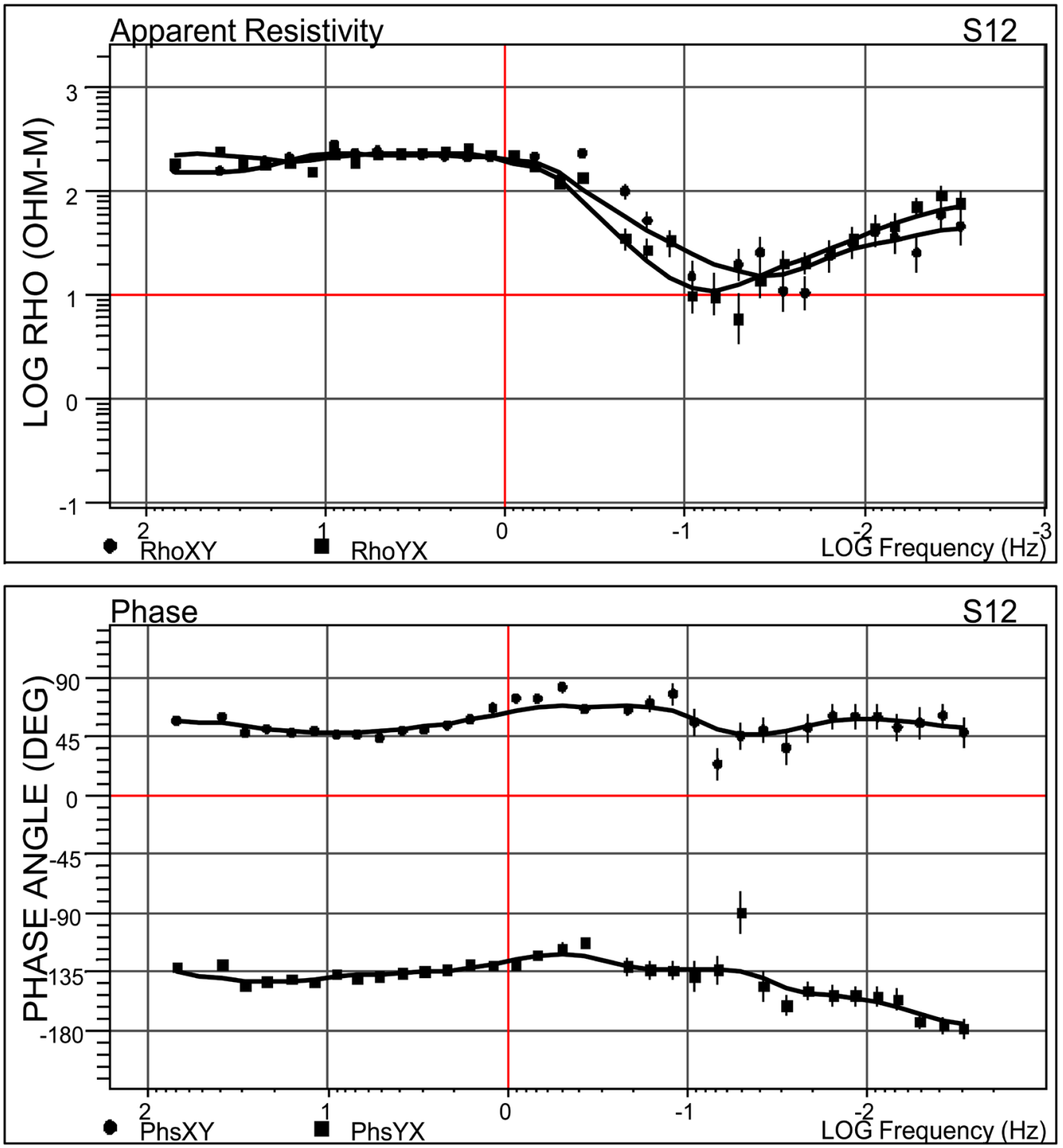

Figure 2. MT sounding curve after GB decomposition and static shift correction for site S12 (Helang) near MCT.

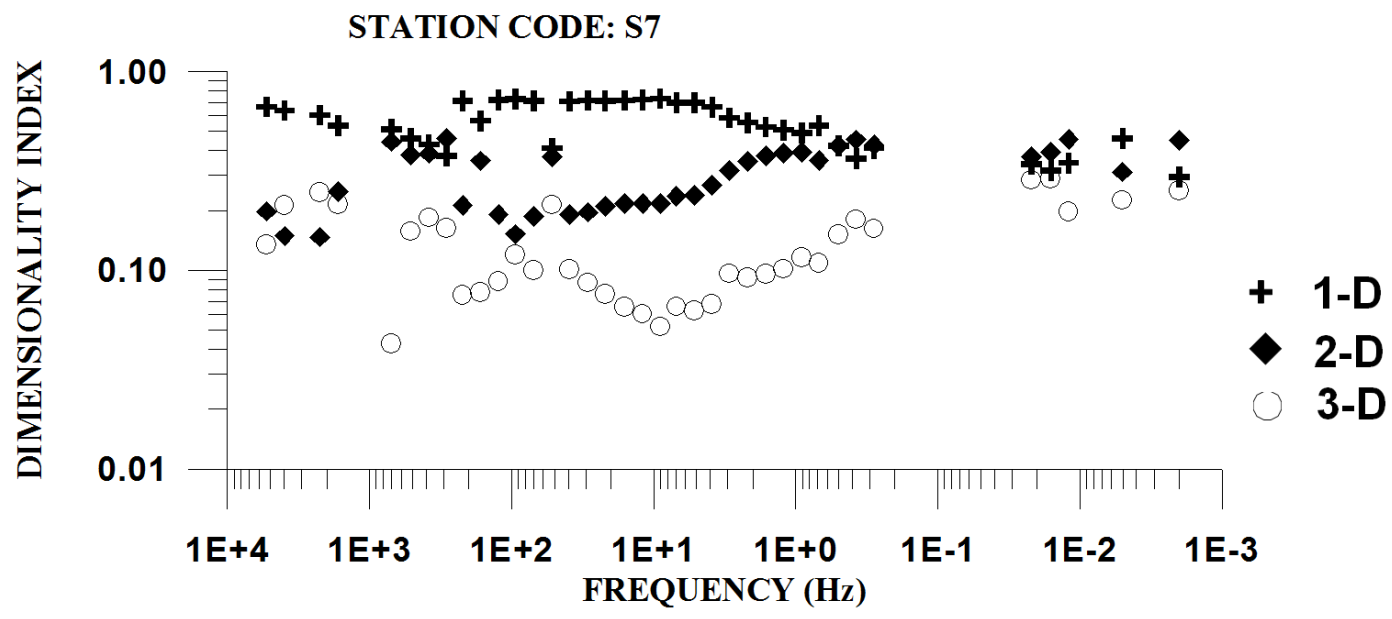

Figure 3. Kao and Orr dimensionality index for site S7 (Diwar), site located near Chamoli. 

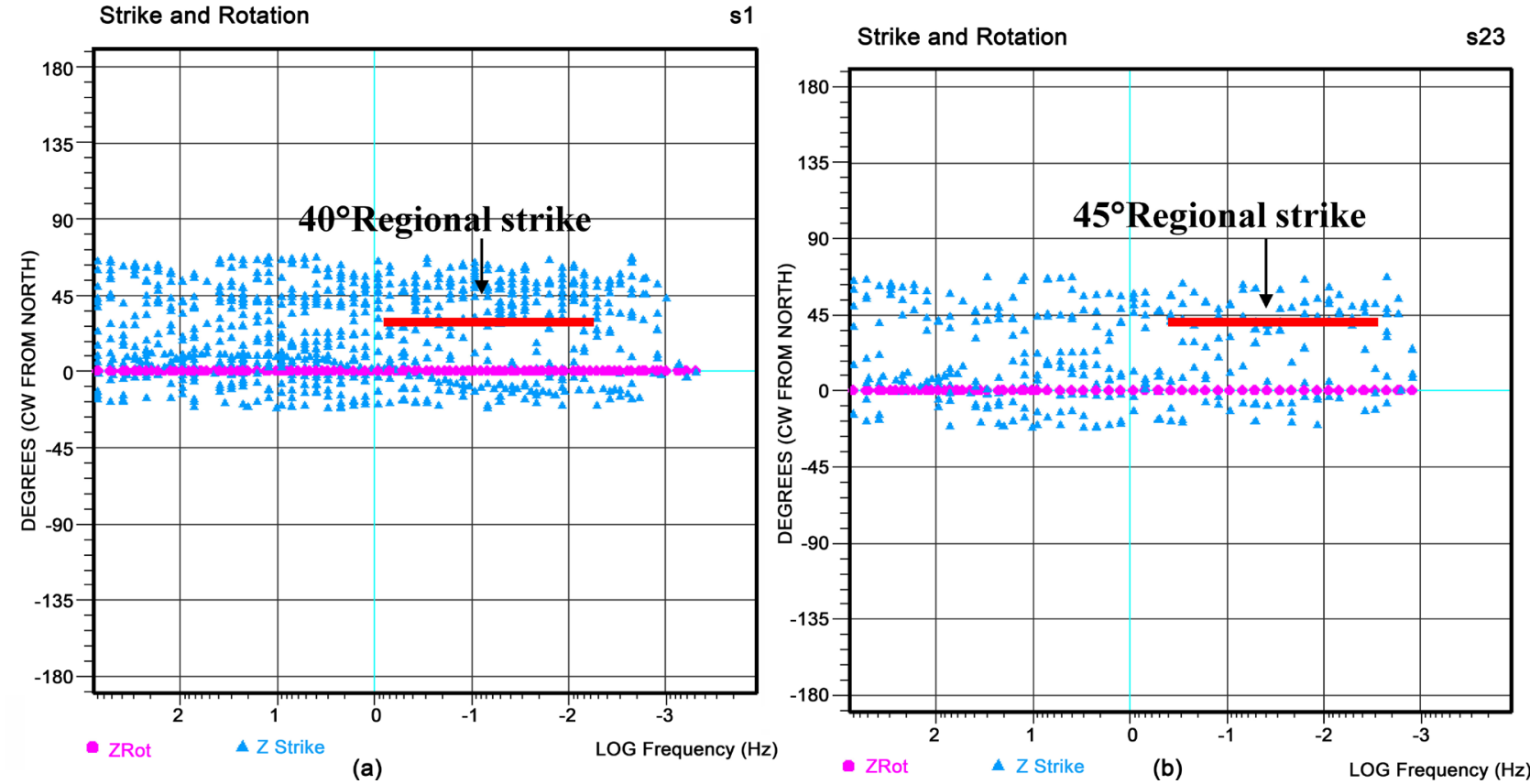

Figure 4. (a) Z strike for all sites in the region (b) Z strike along Gaucher-Joshimath profile.

are fixed to get the best fit model. As can be seen in shallow and deeper sections of 2D model from the Figure 5(a), Figure 5(b) the site S23 shows very thin conductive sediments $(50 \mathrm{ohm} . \mathrm{m})$ upto $500 \mathrm{~m}$ depth in shallow section followed resistive structure upto $10 \mathrm{~km}$ depth. Further deep a conductive structure (50 $100 \mathrm{ohm} . \mathrm{m}$ ) upto $35 \mathrm{~km}$ depth is seen followed by high resistive structure. Similar type of structure is observed near site S22 also with a conductive (50 - 100 ohm.m) feature at $5-20 \mathrm{Km}$ depth and then high resistive structure of the order of $>1000 \mathrm{ohm} . \mathrm{m}$. Anomalous conductive upper crustal feature (1-2 Ohm.m) is obtained near sites 10 and 3. The site S12 also shows conductive upper crustal structure $(20 \mathrm{Ohm} . \mathrm{m})$. One of the interesting feature delineated along the profile is a dipping conductor $(50-100 \mathrm{ohm} . \mathrm{m})$ at $15-30 \mathrm{~km}$ towards south-west and $30-40 \mathrm{~km}$ depth towards NE. At the end of the profile near site S20, near Joshimath also good conductive sediments from $1 \mathrm{~km}$ to $2 \mathrm{~km}$ depths followed by moderate resistive structure $(200 \mathrm{ohm} . \mathrm{m})$ underlain by high resistive structure (>1000 ohm.m) and then a dipping conductor $(50-100$ ohm.m) is seen at depths of about $40-50 \mathrm{~km}$ near the site. Delineation of a deep dipping conductor is one of the interesting feature obtained from the present study. The observed and computed data for the model matches well for all the sites. Figure 6(a), Figure 6(b) shows the fit between the observed and computed apparent resistivity sections for TM and TE mode and in Figure 7(a), Figure 7(b) the fit between observed and computed apparent resistivity and phase for few individual sites S22, S10, S12, S3 for TE and TM mode data are presented.

\section{Results and Discussion}

Electrical conductivity variation in the crust can be due to various factors such as the presence of fluids pore distribution and also petrological characteristics of 

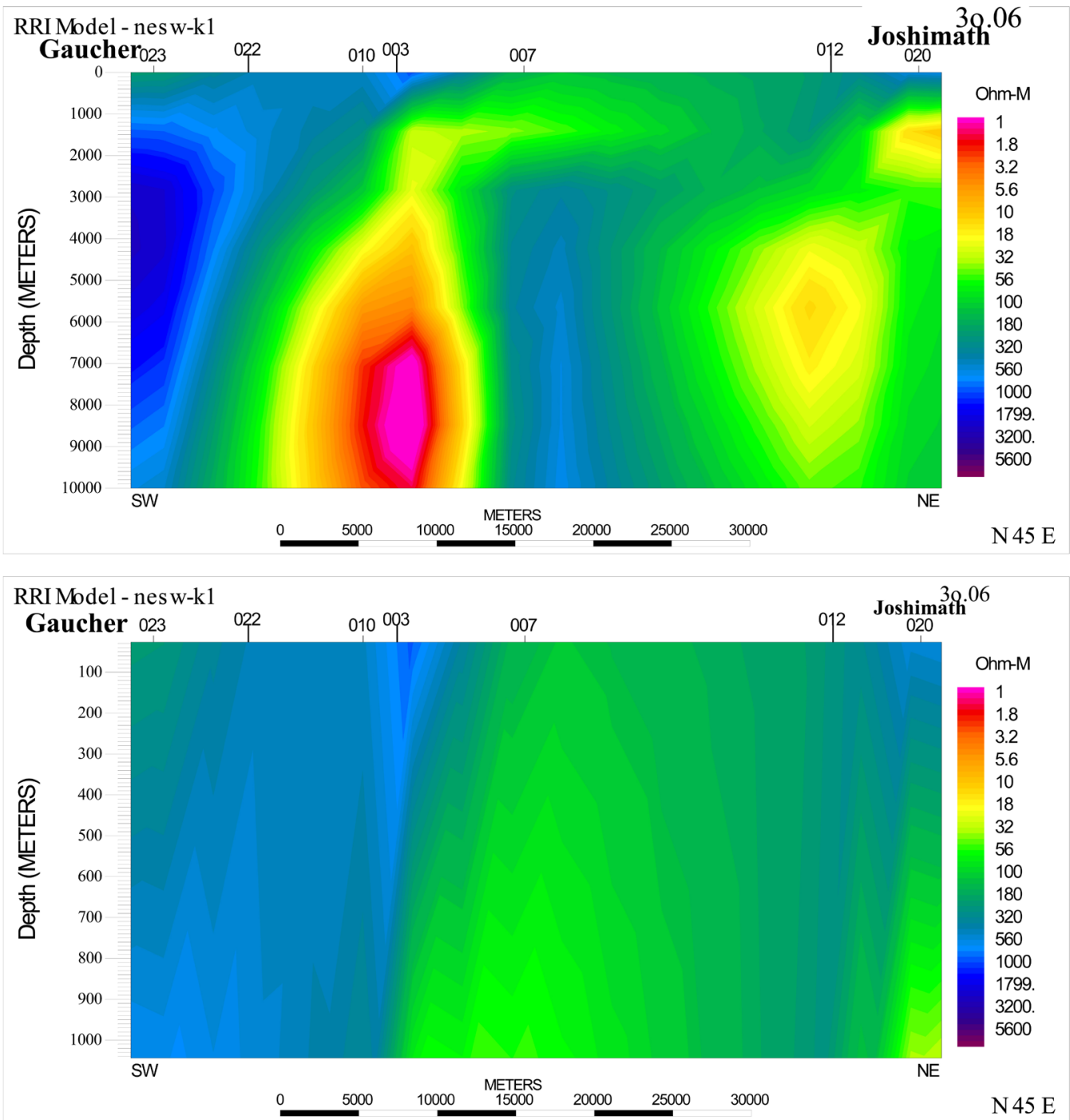

(a)

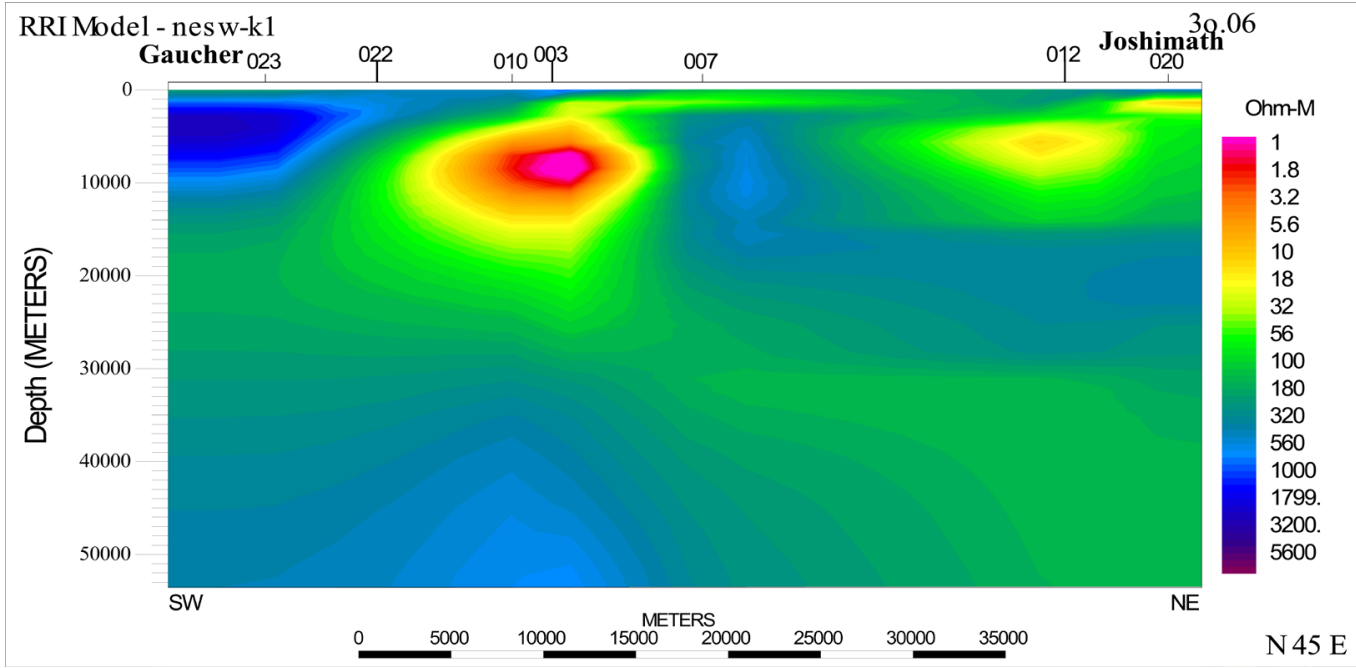

(b)

Figure 5. (a) 2-D RRI model shallow section along Gaucher-Joshimath profile: (i) (1 - $10 \mathrm{~km})$, (ii) $(0-1$ $\mathrm{km})$; (b) 2-D RRI model deeper section along Gaucher-Joshimath profile (0 - $50 \mathrm{~km}$ ). 

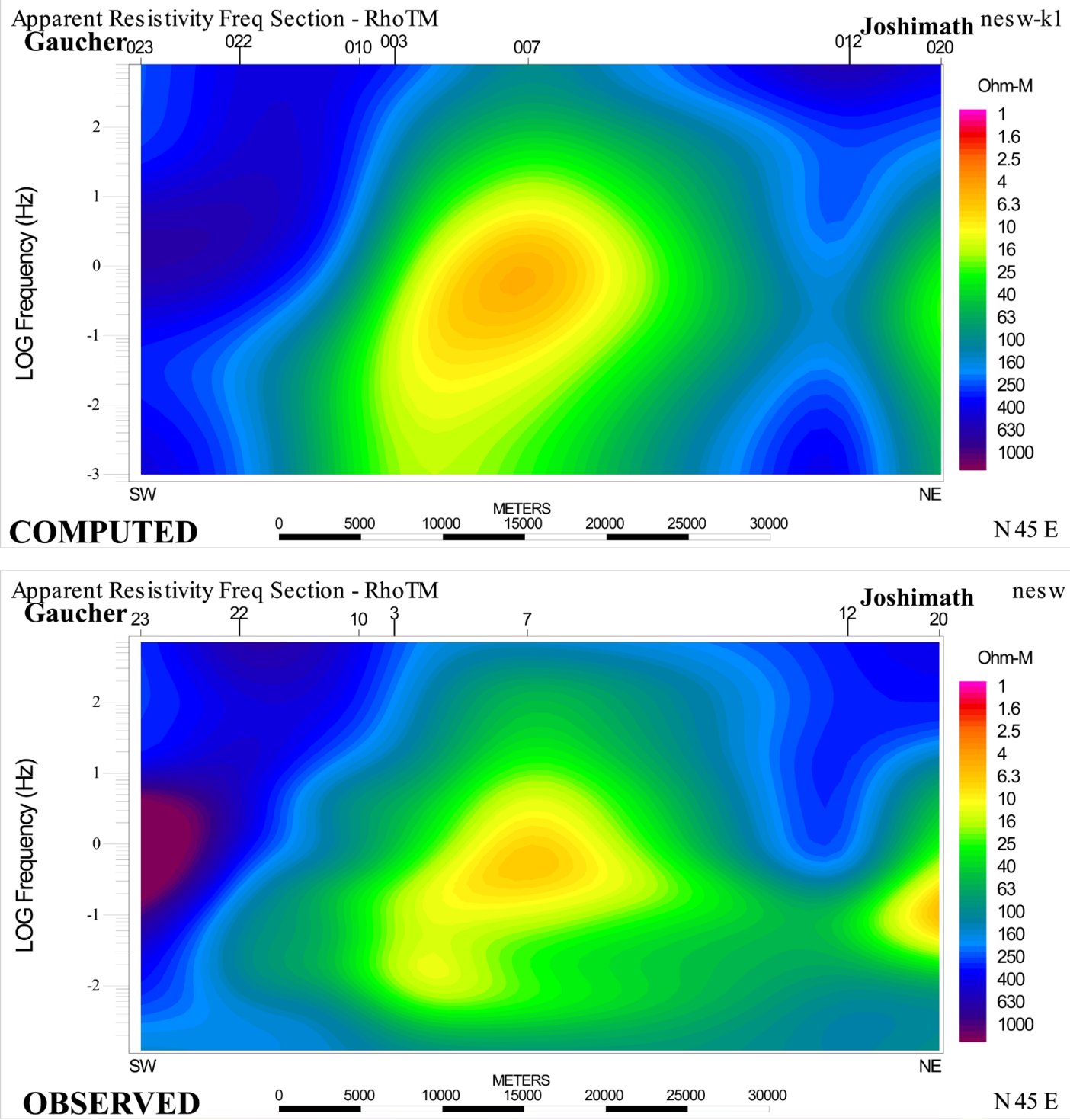

(a)

Apparent Resis tivity Freq Section - RhoTE

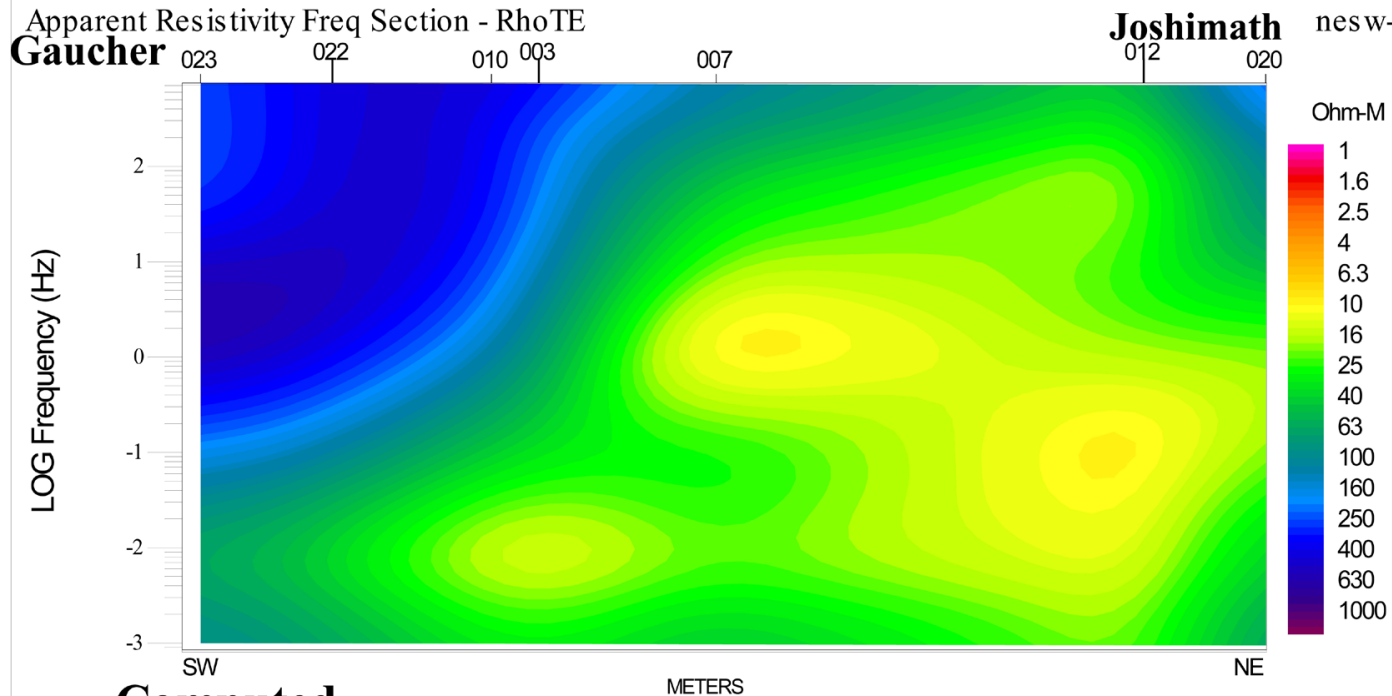

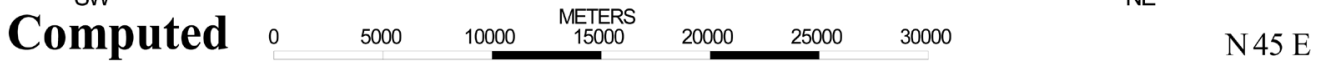




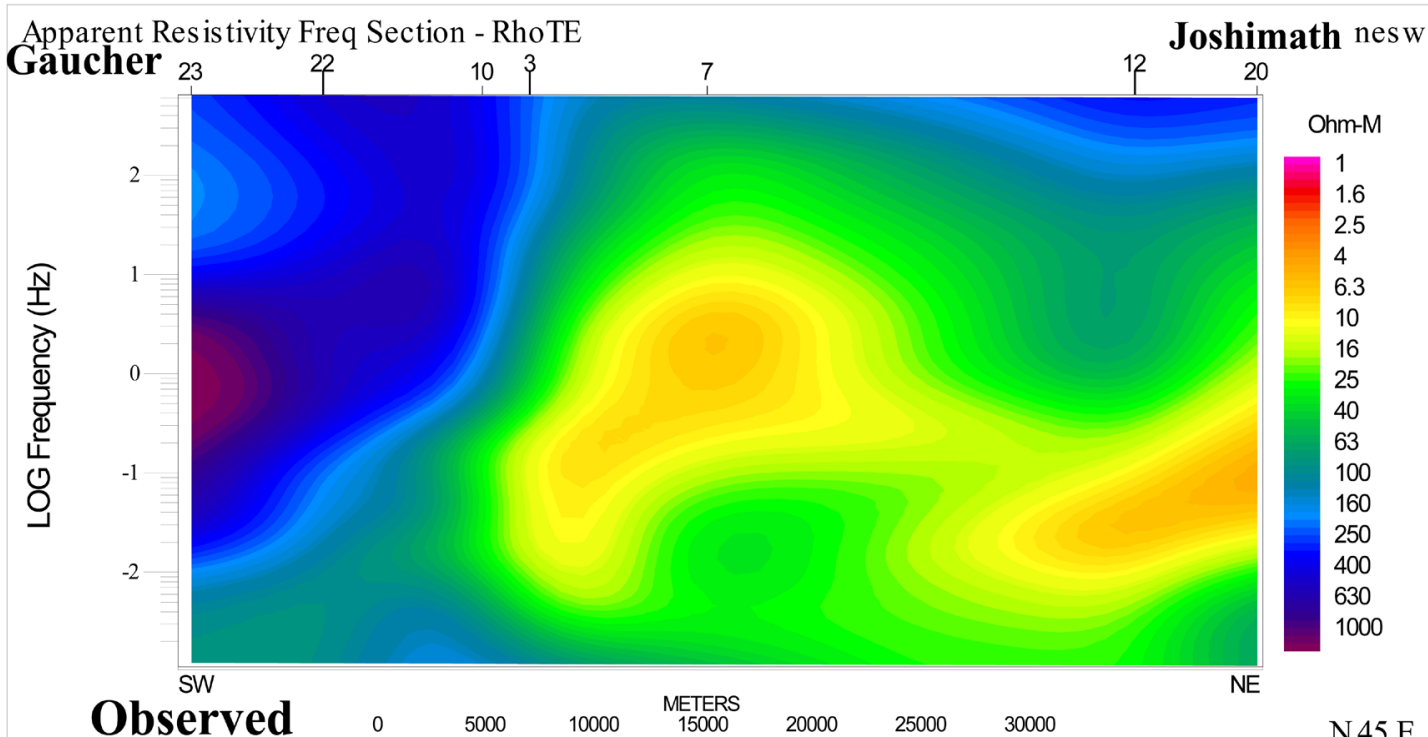

(b)

Figure 6. (a) 2-D fit between computed and observed apparent resistivity response for TM mode data; (b) 2-D fit between computed and observed apparent resistivity response for TE mode data.

the rocks. Anomalous high conductive zones reflect the presence of connected conductive phases such as brine solutions, conductive minerals with partial melts (Marquis and Hyndman, 1992 [15]; Yardley and Valley 1997 [16]). In such a scenario good correlation between electrical and geological structures are expected. It is noticed in the past that more seismic activity is reported near the sharp variation in the geological structures and also across the complex fault zones. The recent MT studies in India near Latur epicentral zone and across complex fault zones in central India have identified anomalous high conductive zones related to seismic activity (Sarma et al. 1994 [33], Gupta et al. 1996 [34], Harinarayana et al. 1998 [35]). Similar results have also been reported across San Andreas fault (Mackie et al., 1997 [36]; Park, 1991 [37]); Lemmonier et al., 1999 [21]; Chen et al., 1996 [38] and Lchiki, 1999 [39]). These studies indicate the significant subsurface conductors in understanding the physical processes related to seismic activity. The 2-D results show anomalous conductive structure located at site S3 and S10. The aftershock activity has been studied by seismic group of NGRI for Chamoli earthquake. The distribution of aftershocks with a magnitude range of $1-4.7$ are recorded during April and May 1999 from five seismic stations (Mandal et al., 2001 [40]) are presented. It is interesting to see the concentration of aftershock activity (Mandal et al., 2001 [40]) falls just north east of this region (Figure 8).

The geoelectric section derived from 1-D modeling and also 2-D modeling are nearly consistent to each other. Additionally, the deep subsurface structure is more clearly seen in 2-D modeling. The shallow geoelectric section $(<10 \mathrm{~km})$ indicates high resistive upper crust below the stations S23 and S22 located towards SW part of the profile near Gaucher. Anomalous conductivity ( $2-5 \mathrm{ohm} . \mathrm{m}$ ) feature is delineated below the stations S10, S3 and S7 from the model. Typical 
thrust signature is evident below the stations S12 and S20 with resistor- conductor -resistor type. Additionally, a prominent moderatively conductive (50 - 100 ohm.m) feature with a thickness of about $10-15 \mathrm{~km}$ at a depth of $10 \mathrm{~km}$ near Gaucher dipping towards NE part of the profile to a depth of $30-40 \mathrm{~km}$ is obtained. Delineation of a such major dipping feature at mid-lower crustal depths is one of the important finding from the present study. This is a clear indication of probable subducting slab type model for the region. Although, such models have been conceptualized from geological and regional tectonic studies, the present study gave a clear evidence for the presence of such a feature in the region.
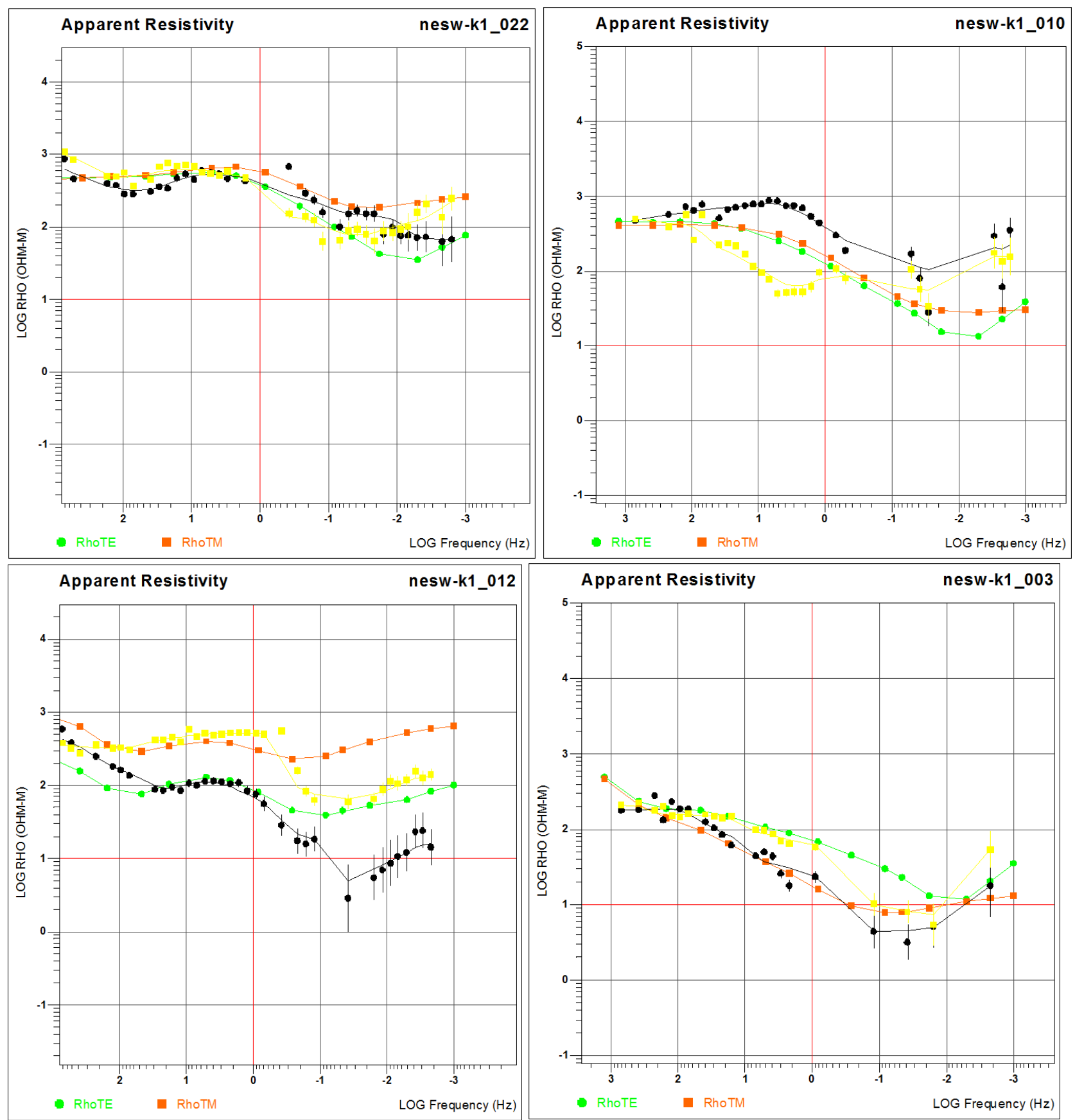

(a) 

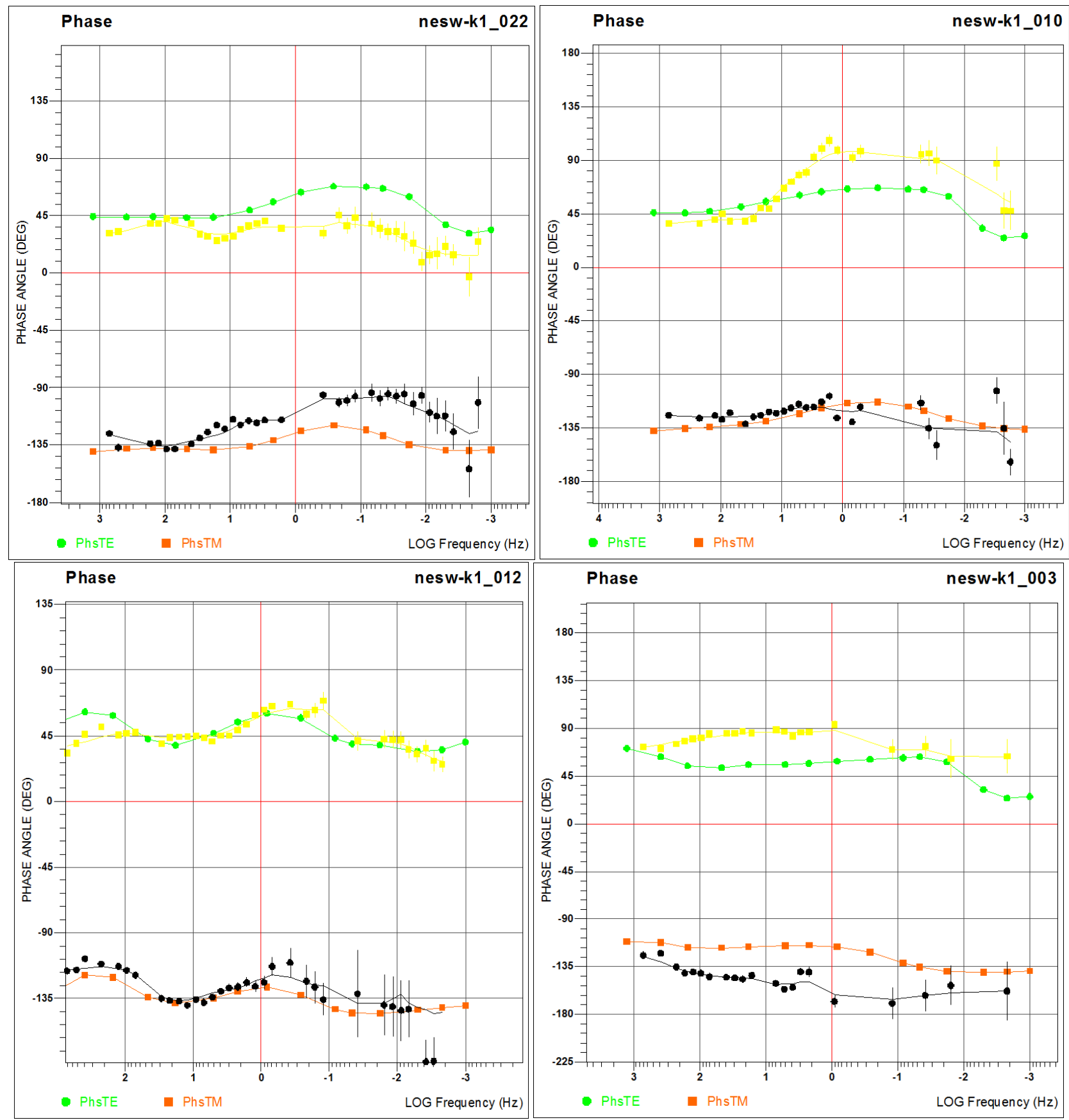

(b)

Figure 7. (a) Fit between observed and computed apparent resistivity responses; (b) Fit between observed and computed phase responses for site S22, S10, S12 and S3 for TE and TM mode data.

The hypocenters of the aftershocks falling close to the profile (10 - $25 \mathrm{~km})$ have been projected and plotted over 2-D geoelectric section (Figure 9). It is of interest to note the concentration of aftershock activity located in the vicinity of the station S7. The station S7 falls very close to the junction of the Gopeshwar fault and also near criss crossing thrusts mapped in the region. Based on these results a schematic model is developed and presented in Figure 10. It can be seen that the concentration of hypocenters are more near the junction of ano- 


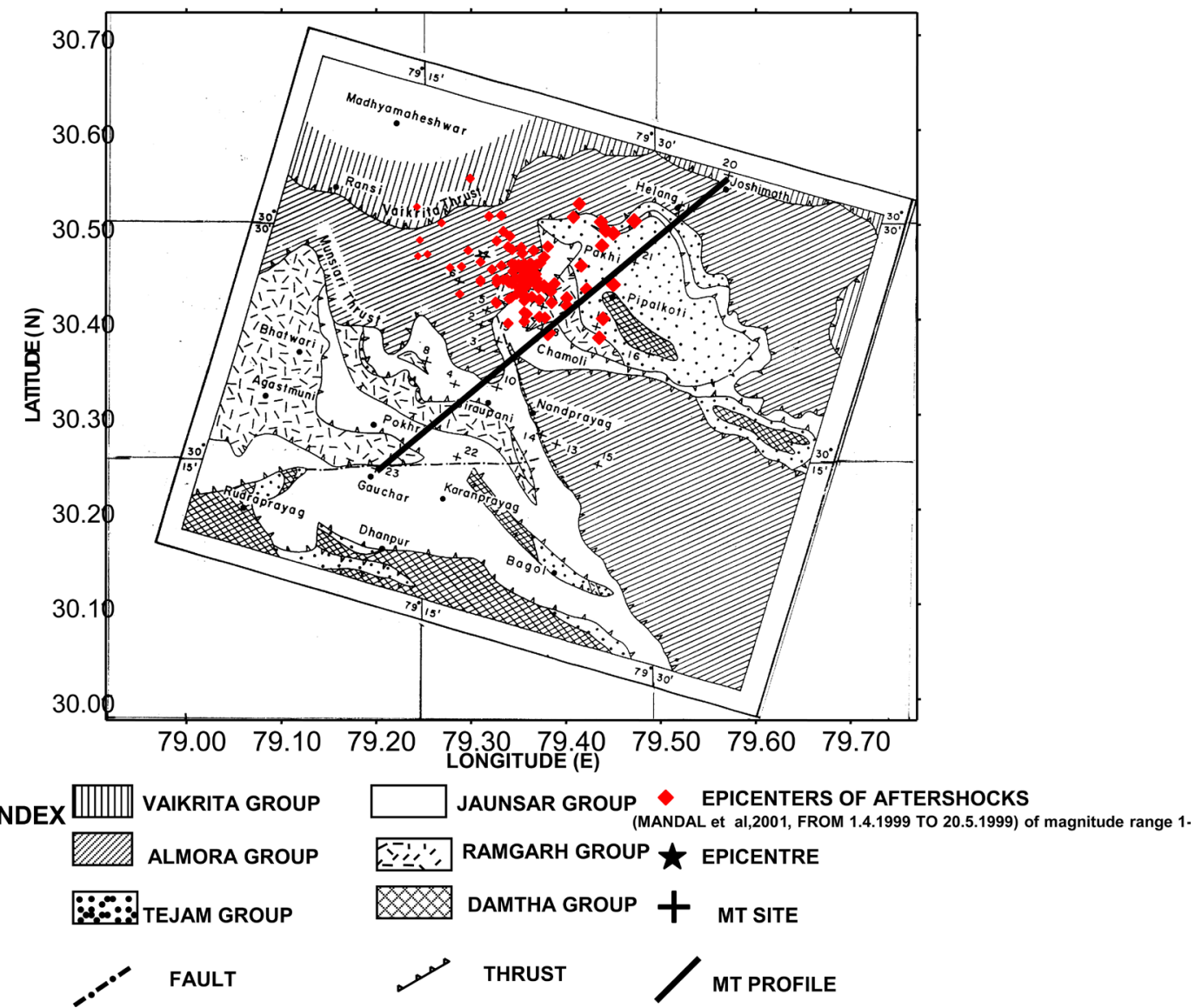

Figure 8. Location map of aftershocks with magnetotelluric (MT) stations in Chamoli earthquake epicentral zone, lesser Himalayas.

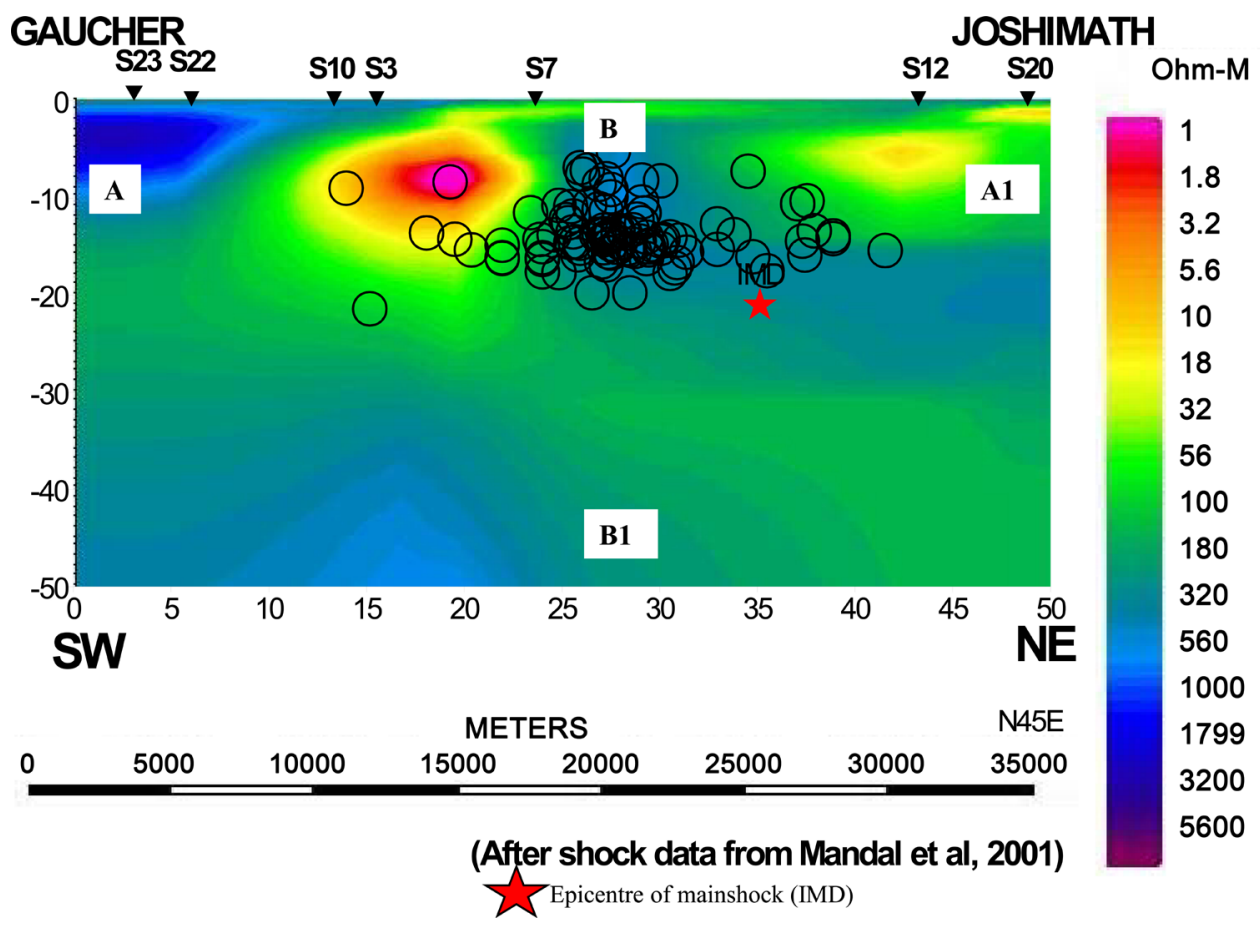

Figure 9. 2-D RRI model along NE-SW profile with hypocentral locations of aftershock data of magnitude range 1 - 4.7 (Source: Mandal et al., 2001). 

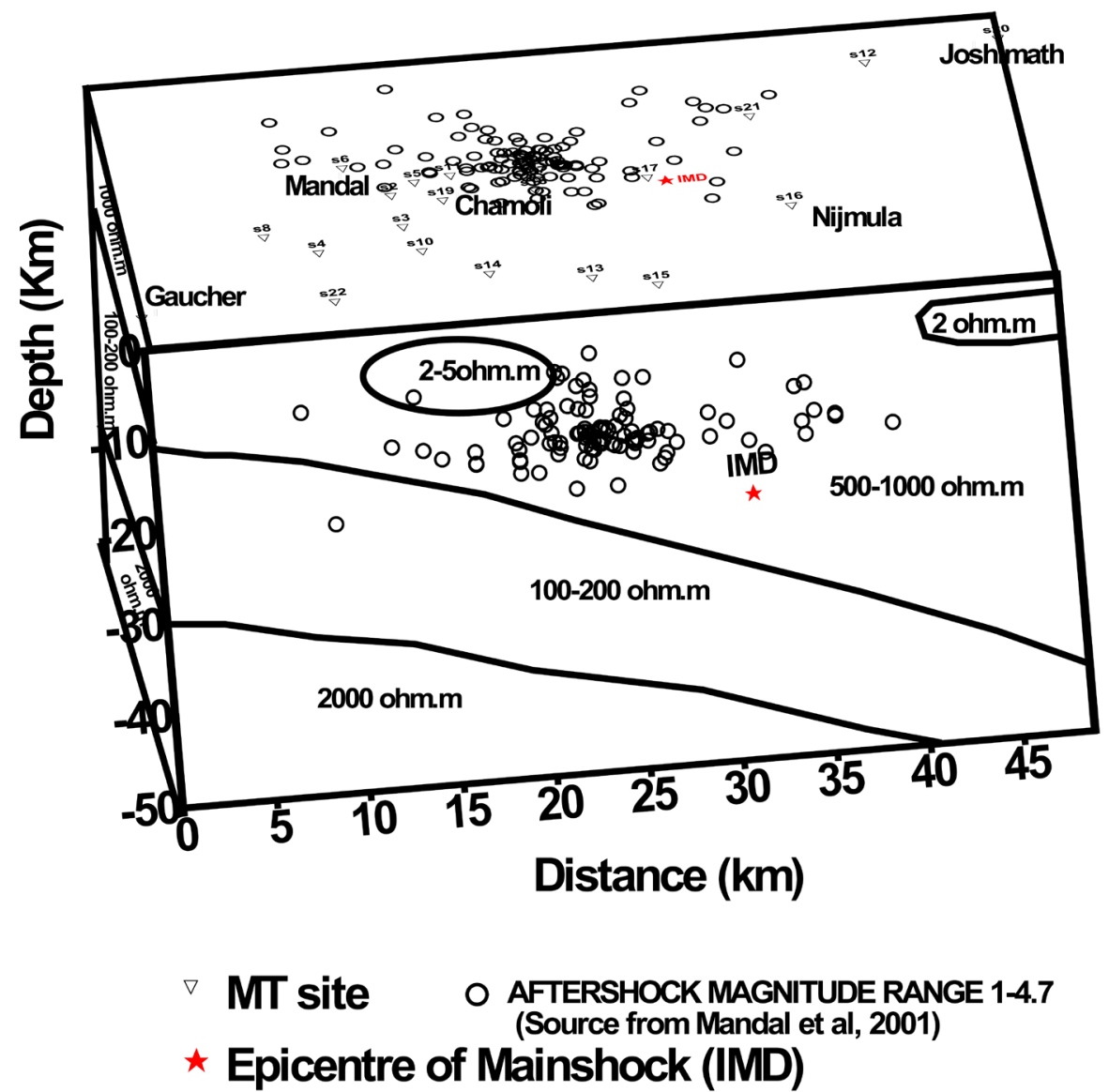

Figure 10. Schematic model of Chamoli Earthquake.

malous conductive feature and the high resistive structure. Based on this important observation, an attempt has been made in the present study to find a relation between aftershock activity and electrical conductivity. This exercise has been carried out along two profiles A-A1 and B-B1 (Figure 9) and the data have been analysed statistically and presented as histogram in Figure 11 and Figure 12. It can be seen that the occurrence of aftershock activity is near zero for high resistive formation. This is true for high conductive formation also. However, concentration of seismic activity can be seen at places where the structure is moderately conductive. This is an indication that concentration of seismic activity is near the transition zone because high resistive rocks are in general can be more brittle and conductive rocks are more ductile in nature.

The hypocenters are located from 5 to $18 \mathrm{~km}$ and with more density between 12 to $15 \mathrm{~km}$ as shown in Figure 9. From structural map of the region the NW-SE oriented Gopeshwar fault also located near the site S3. From such a correlation it can be conjectured that probably the Gopeshwar fault might have been reactivated and triggered the Chamoli earthquake.

\section{Conclusions}

1) The 2-D geoelectric section derived along Gaucher-Joshimath profile has clearly established the presence of a mid-lower crustal conductor and gave a 


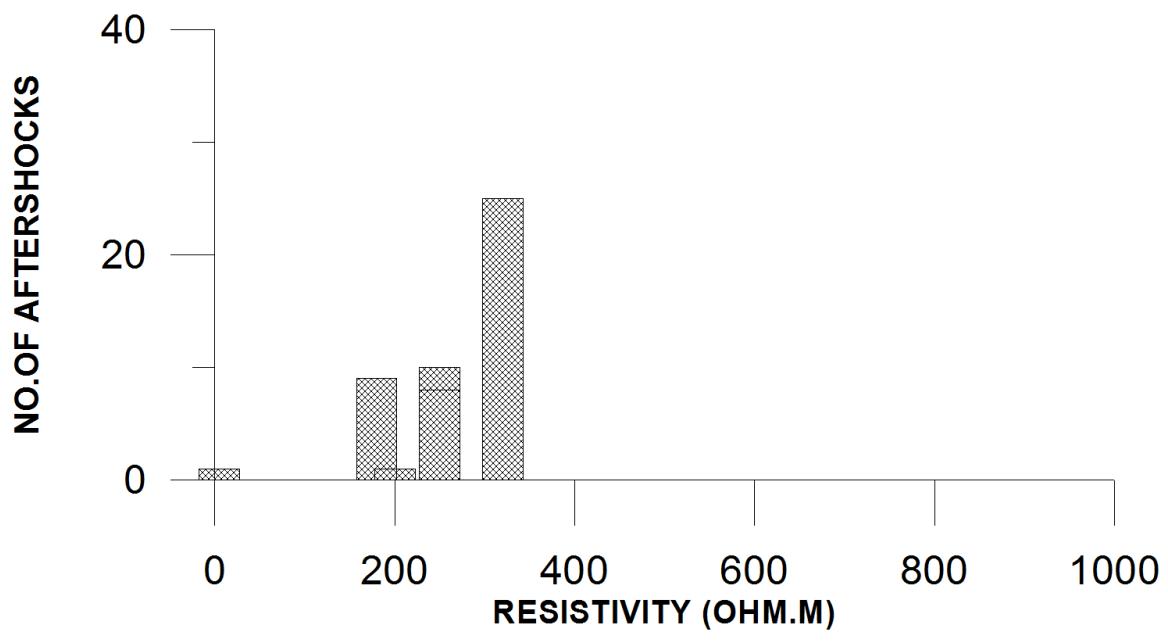

Figure 11. Resistivity vs. No. of aftershocks for Chamoli region for profile A-A1 as shown in Figure 9 at $10-20 \mathrm{~km}$ depth.

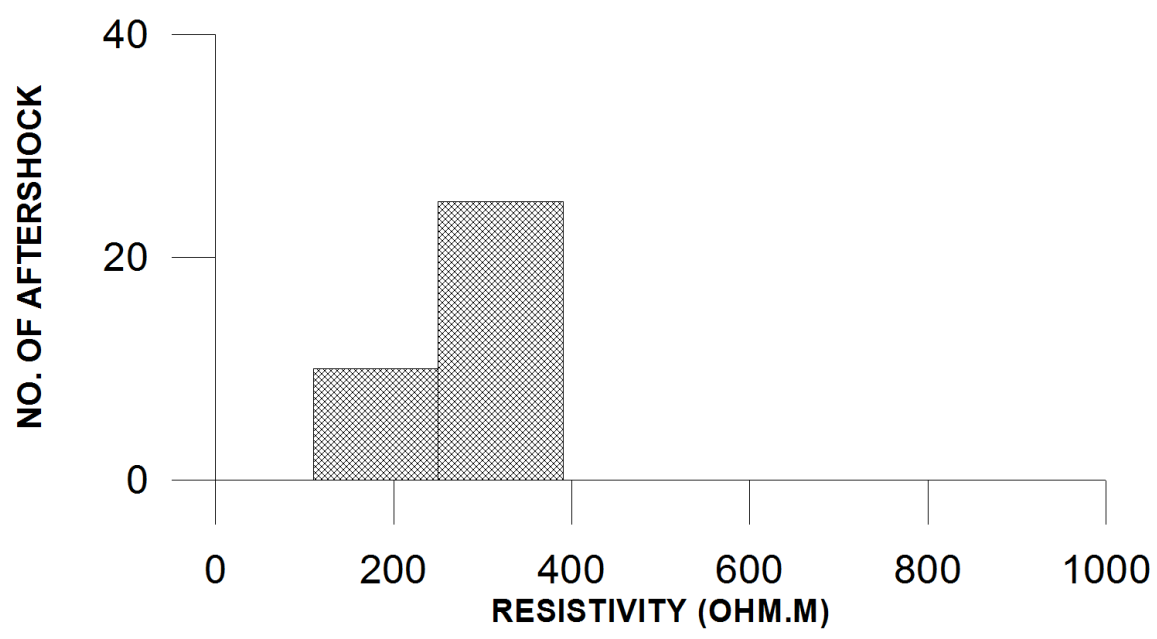

Figure 12. Resistivity vs. No. of aftershocks for Chamoli region for profile B-B1 (Vertical) as shown in Figure 9 at $10-20 \mathrm{~km}$ depth.

clinching evidence for dipping signature, this is an indication for probable existence of a major tectonic feature in the region.

2) Concentration of seismic activity is observed (Mandal et al., 2001 [40]) adjacent to the anomalous geoelectric structures and located near the junction of Gopeshwar fault and thrust zones as discussed in Figure 8 and Figure 9.

3) The location of hypocenters are neither in the anomalous conductive feature near the stations S3 and S7 nor within the high resistive feature but at the junction of the resistor and conductor (Figure 9) from this observation one can conclude that hypocenters are located in the ductile-brittle transition zone. This observation has been derived based on the analysis of the data of electrical conductivity and aftershock activity. It is also observed that the concentration of hypocenters is located just above the deeper dipping conductive feature (Figure 9).

4) From our study, it is observed that electrical conductivity and seismic activity has a relation. This is clear that the more cluster of seismic activity is occur- 
ring close the anomalous conductivity structure. This means the area of anomalous conductivity is a weak zone and thus more seismic activity is reflected in the region.

5) The main direct application of the paper is to avoid large construction activity close to the anomalous conductivity as more seismic activity may occur. Another application is that one need to avoid concentration of large human settlements nearer to the location.

\section{Acknowledgements}

The author gratefully acknowledges the Director, N.G.R.I, Hyderabad, India and Dr. T. Harinarayana Director, GERMI, Gujarat, India for allowing to publish this work.

\section{References}

[1] Molnar, P. and Chen, W.P. (1983) Focal Depths and Fault Plane Solutions of Earthquakes under the Tibetan Plateau. Journal of Geophysical Research: Solid Earth, 88, 1180-1196. https://doi.org/10.1029/JB088iB02p01180

[2] Nakata, T. (1989) Active Faults of the Himalaya of India and Nepal. GSA Special Papers, 232, 243-264. https://doi.org/10.1130/spe232-p243

[3] Demets, C., Gordon, R.G., Argus, D.F. and Stein, S. (1990) Current Platemotions. Geophysical Journal International, 101, 425-478.

[4] Bilham, R., Blume, F., Bendick, R. and Gaur, V.K. (1998) Geodetic Constraints on the Translation and Deformation of India: Implications for Future Great Himalayan Earthquakes. Current Science, 74, 213-229.

[5] Gupta, H.K., Khanal, K.N., Upadhyay, S.K., Sarkar, D., Rastogi, B.K. and Duda, S.J. (1995) Verification of Magnitudes of Himalayan Region Earthquakes of 1903-1985 from Gottingen Observatory. Tectonophysics, 244, 267-284.

[6] Kayal, J.R., Singh, O.P., Chakraborthy, P.K. and Karunakar, G. (2001) Aftershock Sequence of the Chamoli Earthquake of March 1999 in the Garhwal Himalaya. Bulletin of the Seismological Society of America.

[7] Raturi, H. (1988) Garhwal Ka ltihash. Bhagirathi Prakashan, Tehri.

[8] Valdiya, K.S. (1980) Neo Tectonic Implication of the Collision of Indian and Asian Plates. Indian Journal of Geology, 61, 1-13.

[9] Kareemunnisa Begum, S. (2003) Deep Geoelectric Structure in Chamoli and Bhuj Earthquake Epicentral Zones, India Using Magnetotelluric Studies. Ph.D. Thesis, Osmania University, Hyderabad, Telangana, 1-260.

[10] Lefort, P. (1975) Himalayas: The Colliding Range Present Knowledge of the Continental Arc. American Journal of Science, 275, 1-44.

[11] Molnar, P. (1990) A Review of the Seismicity and the Rate of the Active Underthrusting and Deformation at the Himalaya. Journal of Himalayan Geology, 1, 131 154.

[12] Bilham, R., Gaur, V.K. and Molnar, P. (2001) Himalayan Seismic Hazard. Science, 293, 1442-1444. https://doi.org/10.1126/science.1062584

[13] Searle, M.P., Parrish, R.R., Hodges, K.V., Hurford, A., Ayres, M.W. and White House, M.J. (1997) Shisha Pangma Leucogranite, South Tibetan Himalaya Field Relations, Geochemistry, Age, Origin and Emplacement. The Journal of Geology, 105, 295-317. https://doi.org/10.1086/515924 
[14] Henry, P., Le Pichon, X. and Goffe, B. (1996) Kinematic, Thermal and Petrological Model of the Himalayan: Constraints Related to Mesomorphism within the Underthrust Indian Crust and Topographic Elevation. Tectonophysics, 273, 31-56.

[15] Marquis, G. and Hyndman, R.D. (1992) Geophysical Support for Acqueous Fluids in the Deep Crust: Seismic and Electrical Relationships. Geophysical Journal International, 110, 91-105.

[16] Yardley, B.W.D and Valley, J.W. (1997) The Petrologic Case for a Dry Lower Crust. Journal of Geophysical Research: Solid Earth, 102, 12173-12185. https://doi.org/10.1029/97JB00508

[17] Gansser, A. (1964) Geology of the Himalaya. InterScience, New York, 289 p.

[18] Ni, J. and Banazangi, M. (1984) Seismotectonics of the Himalayan Collision Zone: Geometry of the Underthrusting Indian Plate beneath the Himalaya. Journal of Geophysical Research: Solid Earth, 89, 1147-1163. https://doi.org/10.1029/JB089iB02p01147

[19] Arora, B.R. and Singh, B.P. (1992) Geomagnetic and Geoelectric Investigations for Seismicity and Seismotectonics of the Himalayan Region. Memoir-Geological Society of India, 23, 223-263.

[20] Cotton, F., Campillo, M., Deschamps, A. and Rastogi, B.K. (1996) Rupture History and Seismotectonics of the 1991 Uttarkashi Himalaya Earthquake. Tectonophysics, 258, 35-51.

[21] Lemonnier, C., Marquis, G., Perrier, F., Avouac, J.-P., Chitrakar, G., Kafle, B., Sapkota, S., Gautam, U., Tiwari, D. and Bano, M. (1999) Electrical Structure of the Himalaya of Central Nepal: High Conductivity around the Mid-Crustal Ramp along the MHT. Geophysical Research Letters, 26, 3261-3264. https://doi.org/10.1029/1999GL008363

[22] Zhao, W., Nelson, K.D., Che, J., Quo, J., Lu, D., Wu, C. and Liu, X. (1993) Deep Seismic Reflection Evidence for Continental Underthrusting beneath Southern Tibet. Nature, 336, 557-559. https://doi.org/10.1038/366557a0

[23] Nelson, K.D., Zhao, W., et al. (1996) Partially Molten Middle Crust beneath Southern Tibet: Synthesis of Project INDEPTH Results. Science, 274, 1684-1688. https://doi.org/10.1126/science.274.5293.1684

[24] Li, S., Unsworth, M.J., Booker, J.R., Wei, W., Tan, H. and Jones, A.G. (2003) Partial Melt or Aqueous Fluid in the Mid-Crust of Southern Tibet? Constraints from INDEPTH Magnetotelluric Data. Geophysical Journal International, 153, 289-304.

[25] Groom, R.W. and Bailey, R.C. (1989) Decomposition of Magnetotelluric Impedance Tensors in the Presence of Local Three-Dimensional Galvanic Distortion. Journal of Geophysical Research: Solid Earth, 94, 1913-1925. https://doi.org/10.1029/JB094iB02p01913

[26] Jones, A.G. (1988) Static Shift of Magnetotelluric Data and Its Removal in a Sedimentary Basin Environment. Geophysics, 53, 967-978.

https://doi.org/10.1190/1.1442533

[27] Kao, D. and Orr, D. (1982) Magnetotelluric Studies in the Market Weight on Area of Eastern England. Geophysical Journal of the Royal Astronomical Society, 70, 323-337.

[28] Lilley, F.E.M. (1974) Analysis of the Geomagnetic Induction Tensor. Physics of the Earth and Planetary Interiors, 8, 301-316.

[29] Lilley, F.E.M. (1976) Diagrams for Magnetotelluric Data. Geophysics, 41, 766-770. https://doi.org/10.1190/1.1440648

[30] Lilley, F.E.M. (1993) Mohr Circles in Magnetotelluric Interpretation (i) Simple 
Static Shift; (ii) Bahr's Analysis. Journal of Geomagnetism and Geoelectricity, 45, 833-839. https://doi.org/10.5636/jgg.45.833

[31] Lilley, F.E.M. (1993) Magnetotelluric Analysis Using Mohr Circles. Geophysics, 58, 1498-1506. https://doi.org/10.1190/1.1443364

[32] Smith, J.T. and Booker, J.R. (1991) Rapid Inversion of Two- and Three-Dimensional Magnetotelluric Data. Journal of Geophysical Research: Solid Earth, 96, 39053922. https://doi.org/10.1029/90JB02416

[33] Sarma, S.V.S., Virupakshi, G., Harinarayana, T., Murthy, D.N., PrabhakarRao, S.E., Veerawamy, K., Madhusudana, M., Sarma, M.V.C and Gupta, K.R.B. (1994) A Wide Band Magnetotelluric Study of the Latur Earthquake Region, Maharashtra, India. Geological Society of India, 101-118.

[34] Gupta, H.K., Sarma, S.V.S., Harinarayana, T. and Virupakshi, G. (1996) Fluids below the Hypocentral Region of Latur Earthquake, India: Geophysical Indicators. Geophysical Research Letters, 23, 1569-1572. https://doi.org/10.1029/96GL01032

[35] Harinarayana, T., Someswara Rao, M., Nagarajan, N., Patro, B.P.K., Raju, A.V.S.N. and Sarma, S.V.S. (1998) Magnetotelluric Field Studies across Narmada-Son-Lineament Zone, Central India. Stable Continental Region (SCR) Earthquake, Chapman Conference, 25-29 January 1998, 128.

[36] Mackie, R.L., Livelybrooks, D.W., Madden, T.R. and Larsen, J.C. (1997) A Magnetotelluric Investigation of the San Andreas Fault at Carrizo Plain, California. Geophysical Research Letters, 24, 1847-1850. https://doi.org/10.1029/97GL01604

[37] Park, S.K., Biasi, G.P., Mackie, R.L. and Madden, T.R. (1991) Magnetotelluric Evidence for Crustal Suture Zones Bounding the Southern Great Valley, California. Journal of Geophysical Research: Solid Earth, 96, 353-376. https://doi.org/10.1029/90JB02078

[38] Chen, L., Booker, J.R., Jones, A.G., Wu, N., Unsworth, M.J., Wei, W. B. and Tan, H. (1996) Electrically Conductive Crust in Southern Tibet from INDEPTH Magnetotelluric Surveying. Science, 274, 1694-1696.

[39] Ichiki, M., Mishina, M., Goto, T., Oshiman, N., Sumitomo, N. and Utada, H. (1999) Magnetotelluric Investigations for the Seismically Active Area in Northern Miyagi Prefecture, Northeastern Japan. Earth, Planets and Space, 51, 351-361. https://doi.org/10.1186/BF03352239

[40] Mandal, P., Padhy, S., Rastogi, B.K., Satyanarayana, H.V.S., Kousalya, M., Vijayaraghavan, R. and Srinivasan, A. (2001) Aftershock Activity and Frequency-Dependent Low Coda Qc in the Epicentral Region of the 1999 Chamoli Earthquake of Mw 6.4. Pure and Applied Geophysics, 158, 1719-1735. https://doi.org/10.1007/pl00001241

[41] Rastogi, B.K. (2000) Chamoli Earthquake of Magnitude 6.6 on 29 March 1999. Journal of the Geological Society of India, 55, 505-514. 
Submit or recommend next manuscript to SCIRP and we will provide best service for you:

Accepting pre-submission inquiries through Email, Facebook, LinkedIn, Twitter, etc. A wide selection of journals (inclusive of 9 subjects, more than 200 journals)

Providing 24-hour high-quality service

User-friendly online submission system

Fair and swift peer-review system

Efficient typesetting and proofreading procedure

Display of the result of downloads and visits, as well as the number of cited articles Maximum dissemination of your research work

Submit your manuscript at: http://papersubmission.scirp.org/

Or contact ojer@scirp.org 